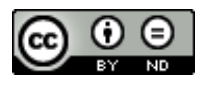

\title{
Świadkowie przeszłości. Zbiory dokumentów z archiwów domowych mieszkańców Radomia i okolic, red. A. Janowska, Radom 2016, ss. 291.
}

$\mathbb{M}$ amy w rękach kolejną publikację prezentującą zawartość domowych „szuflad”. Jest to dowód na niesłabnące zainteresowanie przeszłością, tą najbliższą, bo dotykającą całe rodziny i miejsc, z których pochodzą. By odtworzyć historię najbliższych, potrzeba zaangażowania nierzadko wielu jej członków. Żmudne badania ksiąg metrykalnych, dokumentów rozsianych po wielu archiwach, ale i same rozmowy z krewnymi, odszyfrowywanie fotografii i innych bezcennych pamiątek po ukochanej babci, dziadku, cioci zajmują wiele godzin, dni, a nawet lat.

Dbałość o archiwa prywatne w XVIII w. była utożsamiana z wyjątkową pozycją stanu szlacheckiego. To w archiwach prywatnych rozwijała się oryginalna myśl archiwalna, a już w XIX w. można mówić o archiwach jako instytucjach narodowych ${ }^{1}$.

Czerpiąc z pięknych tradycji wielkich archiwów prywatnych, które były wręcz nośnikiem historii narodowej, powinno pójść się o krok dalej i uświadamiać, że każda z pozoru nieistotna anegdota lub zapiski przodków są nieocenionym źródłem historycznym, które zasługują na odpowiednie zabezpieczenie i upamiętnienie. Jest to wyzwanie zarówno dla archiwów państwowych, jak i innych organizacji, mających na celu rozbudzanie świadomości. Zwrócić uwagę należy na ciągle zmieniające się nośniki i miejsca upamiętnienia indywidualnych - rodzinnych opowieści, i zorganizować to tak, aby mogły być dostępne dla następnych pokoleń.

Wydawnictwo pokazuje, jak ważne jest dla nas pochodzenie. Choć tradycja gromadzenia pamiątek rodzinnych niejednokrotnie poddawana była próbom, tu odradza się

1 W. Chorążyczewski, A. Rosa, B. Bewicz, Manifest albo dekalog twórcy archiwum prywatnego, „Archiwa - Kancelarie - Zbiory” 2013, nr 4 (6), s. 227. 
pragnienie poznania historii przodków - nie tylko tych „szlachetnie” urodzonych, ale też próby zrozumienia kim się jest.

Archiwum Państwowe w Radomiu inspirując się trwającą już od kilku lat akcją „Zostań rodzinnym archiwistą” - postanowiło w 2015 r. zorganizować wystawę opierającą się na materiałach, które wielu mieszkańców z regionu przechowuje we własnych domach. Do instytucji zgłosiło się przeszło 30 osób, chcących podzielić się unikalnymi, w większości sentymentalnymi, pamiątkami po przodkach. Pokłosiem wystawy jest opublikowany katalog: Świadkowie przeszłości. Zbiory dokumentów z archiwów domowych mieszkańców Radomia i okolic, pod redakcją Anny Jankowskiej, obejmujący omówienie rodzinnych zbiorów, z krótkim wprowadzeniem także w historię rodziny. Redaktor wydania zaznaczyła, że tom charakteryzuje się swobodą autorów w wyborze prezentowanych pamiątek, jak i tekstów wprowadzających. Pamiątki rodzinne to głównie zdjęcia, świadectwa, odznaczenia, legitymacje, a więc wszelkie dowody: walki, uczestnictwa, członkostwa itp. Wśród dokumentów znalazły się także karty pamiętników, wiersze, pocztówki, listy. Właśnie te ostatnie materiały są bezcennym pomostem łączącym dawne pokolenia ze współczesnymi, kluczem do poznania tego, co już przeminęło. Opowieści o przodkach to jedno, natomiast uwiecznione myśli, to niepowtarzalna okazja odkrycia opowieści osoby, której już nie ma.

Publikacja jest wartościowa, gdyż każdy rozdział - historia rodziny - jest niepowtarzalny. Wydawcy, dzięki pozostawieniu swobody autorom w tworzeniu krótkich narracji rodzin, nadali jej oryginalny charakter. Trzydzieści cztery mikrohistorie pióra dwudziestu czterech autorów, otwierają przed czytelnikami karty intymnej historii własnej rodziny. Część autorów zdecydowało się na rzetelne przedstawienie drzewa genealogicznego, dokładnie podając daty narodzin i zgonów, miejsca zamieszkania, wykształcenia i późniejszych zajęć, o ile mieli dostęp do tej wiedzy. Inni zdecydowali się na bardziej spontaniczne przekazanie informacji o swoich krewnych, z anegdotami i krótkimi opowieściami. Również zdjęcia czy inne pamiątki zostały przez nich szerzej opisane, co czytelnikowi podsunęło tropy interpretacyjne.

W albumie jest wiele nawiązań do Radomia. Część historii rodzinnych w tym miejscu zaczyna się, bądź kończy. Wskazywane są ulice, domy, w których mieszkali lub nadal mieszkają rodziny autorów, dawne miejsca pracy i wiecznego spoczynku. Niestety informacje dotyczące samego miasta są dość skąpe i odbiorca nie może w pełni odtworzyć klimatu dawnych miejsc. Niemniej jest to jakaś wskazówka dla badaczy historii lokalnej.

Zamieszczone w katalogu reprodukcje dokumentów i fotografii ilustrują nie tylko zawartość poszczególnych archiwów rodzinnych, ale pokazują historię na tle dziejów regionu, czy kraju. Stanowią ważne źródło do poznania danej osoby, rodziny, a także obyczajowości i życia codziennego minionych lat. Zaprezentowane dokumenty, jak i ich treść stanowią o tożsamości radomskich rodzin. Dla czytelnika tom może być ciekawą 
i inspirującą pozycją. W niejednym być może rozbudzi pragnienie poznania historii własnej rodziny, a nawet stworzenia swojego rodzinnego archiwum.

Często rodziny nie zdają sobie sprawy z wartości przechowywanych materiałów, są to nie tylko pamiątki rodzinne, ale też cenne źródła historyczne wykorzystywane do badań nad mikrohistorią, czy historią codzienności. Dzięki publikacji mamy możliwość poznania różnorodnych materiałów, tworzących archiwa rodzinne, ale i, co często jest pomijane, dostrzec jak ważną rolę w kształtowaniu i pielęgnowaniu pamięci rodzinnej odgrywają domowi archiwiści.

Katalog towarzyszący wystawie jest cennym materiałem do analizy przechowywanych materiałów i rodzinnych pamiątek. Opowiada czym według rodziny jest ślad przeszłości. W poniższej tabeli zebrane zostały materiały, które rodziny postanowiły upublicznić. Każde archiwum rodzinne posiada fotografie, okazuje się to fundamentalną pamiątką, obrazem przeszłości. Dużą rolę odgrywają wszelkie poświadczenia takie jak: legitymacje, dyplomy, świadectwa, akta ślubu itp. Zachowuje się je z kilku względów, miały moc prawną, służyły jako dowody i dzięki nim można było zaświadczyć np. o tożsamości - co jest w wielu sprawach niezbędne, ale też pokazuje kim byli przodkowie, czym się zajmowali, jakie mieli pasje i zadania w swoim życiu. Stosunkowo niewiele zachowuje się „intymnych” pamiątek, pamiętników, listów, dzieł, czy bibelotów po przodkach. To, co sprawia kim jesteśmy, mówi jacy jesteśmy, nie zawsze się zachowuje. W dwóch przypadkach zdecydowano się zamieścić artefakty: skrzynia i skrzypce - które są w rodzinie od wielu lat i opowiadają historie o dawnych właścicielach. Bywa, że świadomie niszczymy osobiste wyznania, staramy się ukryć niewygodne fakty i kreujemy siebie na nowo, dlatego tak rzadko w zbiorach pozostają osobiste historie - oddziałujące na emocje.

Radomskie archiwum państwowe decydując się na publikację rodzinnych kolekcji z ich historiami, pokazuje jak ważna jest dla nas pamięć o rodzinie, jak można ocalić ją od zapomnienia i sprawić, by żyła wśród potomków.

\section{Spis rodzinnych pamiątek}

\begin{tabular}{|l|l|l|}
\hline \multicolumn{1}{|c|}{ Rodzina } & \multicolumn{1}{|c|}{ Dokument } & \multicolumn{1}{c|}{$\begin{array}{c}\text { Fotografie/ medale/ } \\
\text { ordery }\end{array}$} \\
\hline Badowscy & $\begin{array}{l}2 \text { dyplomy } \\
2 \text { legitymacje } \\
4 \text { karty pocztowe }\end{array}$ & 2 fotografie \\
\hline Klimkowscy & $\begin{array}{l}1 \text { legitymacja } \\
3 \text { świadectwa } \\
1 \text { książka }\end{array}$ & 5 fotografii \\
\hline
\end{tabular}


Spis rodzinnych pamiątek (cd.)

\begin{tabular}{|c|c|c|}
\hline Rodzina & Dokument & $\begin{array}{l}\text { Fotografie/ medale/ } \\
\text { ordery }\end{array}$ \\
\hline Mirkowscy & $\begin{array}{l}1 \text { legitymacja } \\
1 \text { zaświadczenie }\end{array}$ & 1 fotografia \\
\hline Pajkertowie & $\begin{array}{l}2 \text { karty pocztowe } \\
1 \text { zaproszenie } \\
1 \text { odpis } \\
1 \text { zaświadczenie }\end{array}$ & 2 fotografie \\
\hline Michalscy i Bajonowie & $\begin{array}{l}\text { indeks } \\
2 \text { zaświadczenia } \\
\text { bilet } \\
2 \text { listy } \\
2 \text { legitymacje } \\
2 \text { świadectwa } \\
\text { umowa zakupu } \\
\text { podziękowania }\end{array}$ & 4 fotografie \\
\hline Momentowiczowie & $\begin{array}{l}\text { zaświadczenie } \\
\text { akt ślubu } \\
\text { wycinek prasowy }\end{array}$ & 4 fotografie \\
\hline Dorocińscy & $\begin{array}{l}\text { akt urodzenia } \\
\text { pamiątka I komunii }\end{array}$ & 6 fotografii \\
\hline Dutkowscy & & 3 fotografie \\
\hline Szwedzińscy & & 13 fotografii \\
\hline Kołodziejscy & $\begin{array}{l}2 \text { dyplomy } \\
3 \text { zaświadczenia } \\
2 \text { legitymacje } \\
\text { świadectwo }\end{array}$ & 7 fotografii \\
\hline Kowalewscy & $\begin{array}{l}\text { wiersz } \\
\text { książeczka do nabożeństwa }\end{array}$ & $\begin{array}{l}14 \text { fotografii } \\
2 \text { obrazki religijne }\end{array}$ \\
\hline Lachowicze & $\begin{array}{l}\text { akt urodzenia } \\
3 \text { legitymacje }\end{array}$ & $\begin{array}{l}6 \text { fotografii } \\
\text { nóż do cięcia papieru } \\
4 \text { medale za zasługi }\end{array}$ \\
\hline $\begin{array}{l}\text { Mańczyńscy } \\
\text { Prokopowicze }\end{array}$ & $\begin{array}{l}\text { karta pocztowa } \\
\text { list } \\
\text { wycinek prasowy }\end{array}$ & $\begin{array}{l}11 \text { fotografii } \\
\text { satyryczny banknot }\end{array}$ \\
\hline
\end{tabular}


Spis rodzinnych pamiątek (cd.)

\begin{tabular}{|c|c|c|}
\hline Rodzina & Dokument & $\begin{array}{c}\text { Fotografie/ medale/ } \\
\text { ordery }\end{array}$ \\
\hline Szwaccy & $\begin{array}{l}\text { pismo dot. uposażenia } \\
\text { powołanie na notariusza } \\
\text { ausweis } \\
\text { książeczka wkładowa }\end{array}$ & 15 fotografii \\
\hline de Tramecourt & $\begin{array}{l}\text { zaświadczenie } \\
\text { list } \\
\text { pismo dotyczące awansu } \\
\text { pismo - powołanie na stanowisko } \\
\text { protokół posiedzenia Wydziału } \\
\text { Powiatowego } \\
\text { wizytówka zakładu rymarskiego }\end{array}$ & $\begin{array}{l}11 \text { fotografii } \\
\text { skrzynia }\end{array}$ \\
\hline Ankiewicze & $\begin{array}{l}2 \text { kalendarze kieszonkowe } \\
2 \text { kartki pocztowe } \\
\text { fragment pamiętnika } \\
\text { zaświadczenie } \\
\text { ustawa towarzystwa Resursy } \\
\text { kontrakt } \\
\text { list miłosny } \\
\text { dyplom } \\
\text { książeczka do nabożeństwa } \\
\text { ulotka reklamowa } \\
\text { tabela absolwentów Szkoły } \\
\text { Podchorążych Rezerwy Artylerii } \\
\text { rękopis książki Ks. Józefa Gackiego } \\
\text { „Klasztor księży Benedyktynów } \\
\text { w Sieciechowie” }\end{array}$ & 3 fotografie \\
\hline Glogierowie & $\begin{array}{l}7 \text { zaproszeń } \\
2 \text { legitymacje } \\
\text { podziękowania } \\
\text { list pożegnalny }\end{array}$ & $\begin{array}{l}6 \text { fotografii } \\
\text { order } \\
2 \text { odznaki }\end{array}$ \\
\hline Kubicowie i Iwańscy & $\begin{array}{l}\text { materiał ulotny - cegiełka, bilet, } \\
\text { karta wyokrętowania } \\
5 \text { legitymacji } \\
\text { bilet }\end{array}$ & $\begin{array}{l}13 \text { fotografii } \\
5 \text { odznak }\end{array}$ \\
\hline
\end{tabular}


Spis rodzinnych pamiątek (cd.)

\begin{tabular}{|c|c|c|}
\hline Rodzina & Dokument & $\begin{array}{c}\text { Fotografie/ medale/ } \\
\text { ordery }\end{array}$ \\
\hline & $\begin{array}{l}2 \text { listy prywatne } \\
\text { świadectwo wstąpienia do } \\
\text { zakonu } \\
\text { teksty piosenek }\end{array}$ & \\
\hline $\begin{array}{l}\text { Wojciechowscy } \\
\text { i Deperasińscy }\end{array}$ & $\begin{array}{l}\text { fragment pamiętnika } \\
6 \text { zaświadczeń o pobytach } \\
\text { w obozach koncentracyjnych } \\
\text { dyplom } \\
\text { świadectwo }\end{array}$ & 8 fotografii \\
\hline Pawlakowie & $\begin{array}{l}3 \text { dyplomy } \\
3 \text { legitymacje } \\
\text { książeczka wojskowa }\end{array}$ & $\begin{array}{l}8 \text { fotografii } \\
4 \text { odznaczenia/ordery/ } \\
\text { medale } \\
\text { z listem potwierdzającym }\end{array}$ \\
\hline $\begin{array}{l}\text { Reymondowie } \\
\text { i Przemyscy }\end{array}$ & $\begin{array}{l}\text { świadectwo } \\
3 \text { pisma różne } \\
\text { akt nadania obywatelstwa } \\
\text { wizytówka } \\
\text { zawiadomienie }\end{array}$ & $\begin{array}{l}5 \text { fotografii } \\
\text { odznaczenie z aktem } \\
\text { nadania }\end{array}$ \\
\hline Pustówkowie & $\begin{array}{l}\text { pismo święte z } 1838 \text { r. } \\
\text { postylla - zbiór kazań z } 1866 \text { r. }\end{array}$ & $\begin{array}{l}5 \text { fotografii } \\
\text { skrzypce }\end{array}$ \\
\hline Idziakowscy & & 8 fotografii \\
\hline Sadurscy & $\begin{array}{l}\text { zawiadomienie } \\
\text { karta zwolnienia } \\
\text { instrukcja broni } \\
\text { legitymacja } \\
\text { wycinek prasowy }\end{array}$ & $\begin{array}{l}8 \text { fotografii } \\
\text { fragment mapy z akcji } \\
\text { „Burza” } \\
\text { naszywka } \\
\text { znaczek }\end{array}$ \\
\hline $\begin{array}{l}\text { Kochmanowie/ } \\
\text { Hoffmanowie }\end{array}$ & & 5 fotografii \\
\hline Lechowie & & 12 fotografii \\
\hline Pobratynowie & 5 zaświadczeń & $\begin{array}{l}3 \text { fotografie } \\
\text { odznaka }\end{array}$ \\
\hline
\end{tabular}


Spis rodzinnych pamiątek (cd.)

\begin{tabular}{|c|c|c|}
\hline Rodzina & Dokument & $\begin{array}{c}\text { Fotografie/ medale/ } \\
\text { ordery }\end{array}$ \\
\hline Przybyszowie & $\begin{array}{l}\text { książeczka do nabożeństwa } \\
\text { ulotka propagandowa } \\
\text { świadectwo }\end{array}$ & fotografia \\
\hline Staniszewscy & $\begin{array}{l}\text { rachunki } \\
\text { ulotka reklamowa }\end{array}$ & 11 fotografii \\
\hline Karol Hartrampf & $\begin{array}{l}2 \text { legitymacje } \\
\text { ausweis } \\
\text { druk z „Jednej akcji” } \\
\text { dyplom } \\
2 \text { pisma }\end{array}$ & 9 fotografii \\
\hline Tedeszwili & $\begin{array}{l}2 \text { świadectwa } \\
\text { podanie } \\
\text { bilet } \\
2 \text { legitymacje }\end{array}$ & 18 fotografii \\
\hline Kazimierz Borkowski & $\begin{array}{l}\text { dowód tożsamości, } \\
\text { przepustka } \\
\text { bilet } \\
4 \text { legitymacje odznaczeń }\end{array}$ & 4 fotografie \\
\hline $\begin{array}{l}\text { Połowcowie, Wiosnowie, } \\
\text { Cedrowie }\end{array}$ & $\begin{array}{l}3 \text { dyplomy } \\
5 \text { zaświadczeń } \\
\text { wycinek prasowy } \\
\text { pismo } \\
\text { mandat delegata } \\
\text { książeczka wojskowa }\end{array}$ & $\begin{array}{l}9 \text { fotografii } \\
2 \text { odznaki z legitymacjami } \\
\text { epolet leśniczego }\end{array}$ \\
\hline $\begin{array}{l}\text { Grobiccy, Makulcowie, } \\
\text { Dzikowscy }\end{array}$ & $\begin{array}{l}2 \text { podziękowania } \\
4 \text { listy } \\
\text { udziały } \\
2 \text { dyplomy } \\
3 \text { zaświadczenia } \\
\text { legitymacja } \\
2 \text { rachunki firmowe, papier } \\
\text { firmowy }\end{array}$ & 5 fotografii \\
\hline
\end{tabular}




\begin{tabular}{|l|l|l|}
\hline Rodzina & \multicolumn{1}{|c|}{ Dokument } & $\begin{array}{c}\text { Fotografie/ medale/ } \\
\text { ordery }\end{array}$ \\
\hline & $\begin{array}{l}\text { 2 powiadomienia } \\
\text { prawo jazdy } \\
\text { dowód rejestracyjny } \\
\text { dokumentacja dot. pojazdu } \\
\text { karta rybacka } \\
\text { książeczka wojskowa }\end{array}$ & \\
\hline
\end{tabular}

Kamila Siuda

(Uniwersytet Mikotaja Kopernika w Toruniu) kamila.siuda@gmail.com

\section{Bibliografia}

Chorążyczewski, Waldemar, Agnieszka Rosa, and Piotr Bewicz. „Manifest albo dekalog twórcy archiwum prywatnego." Archiwa - Kancelarie - Zbiory 4(6), (2013): 225-234. 